\title{
ЧИСЛЕННОСТЬ И СТРУКТУРА НАСЕЛЕНИЯ КУКШИ PERISOREUS INFAUSTUS (AVES, PASSERIFORMES) В ЯКУТИИ
}

\author{
Н. Н. Егоров, Н. И. Гермогенов, А. Н. Секов, А. В. Лосоров \\ ФГБУН Институт биологических проблем криолитозоны СО РАН, г. Якутск \\ E-mail: epusilla@mail.ru; sterkh-yrcu@mail.ru; sekof@mail.ru
}

\begin{abstract}
Исследования проводили в различных подзонах таежной Якутии в 1975-2015 гг. На двух видовых модельных площадках (471 и 1360.3 га) в светлохвойных среднетаежных лесах близ г. Якутск они носили мониторинговый характер: учеты численности, определение статуса птиц на основе кольцевания и т. д. Численность птиц подвержена пространственно-временной динамике. Плотность гнездования вида меняется в зависимости от ландшафтно-экологических условий обитания. Местообитания в северной тайге он населяет с менее выраженным «гнездовым консерватизмом». Численность птиц минимальна в пред- и гнездовой периоды, максимальна - в поствыводковый. Изменения ее по годам носят, вероятно, циклический характер и кореллируют с динамикой некоторых среднегодовых показателей температуры воздуха. Предполагается, что под влиянием таких демографических особенностей вида, как невысокая в целом эффективность размножения и малая сохранность на территории рождения сеголетков, у него сформировался специфический механизм регуляции численности. Вероятно, восполнение потерь популяции обеспечивается периодически наблюдаемыми локальными «вспышками» рождаемости. Вследствие широкой натальной дисперсии, определяемой жесткой внутривыводковой конкуренцией, большая часть молодых птиц перераспределяется по занимаемой популяцией территории вне мест своего рождения. В населении выделяются две основные категории птиц: «резиденты» - осевшие на территории и ведущие оседлый образ жизни птицы инорайонного и местного происхождения, составляющие основу населения, обеспечивающие его устойчивость и воспроизводство, и «иммигранты» - птицы, ежегодно впервые регистрируемые и кратковременно пребывающие (нередко с гнездованием) на территории, придающие населению определенную динамичность. Около половины населения птиц, в котором преобладают особи от $3+$ лет и старше, составляют пары, продолжительность их гнездования в неизменном составе достигает не менее 7 сезонов. Максимальный возраст самок соответствует предельно возможному для периода наблюдений $-9+$, самцов $-8+$ лет. Часть пар имеет пассивного (инертного) партнера, обычно из числа «иммигрантов».
\end{abstract}

Ключевые слова: Якутия, кукша, половозрастной состав популяции, статус птицы.

DOI: 10.34078/1814-0998-2019-2-73-88

Кукша широко распространена в северной Евразии и, благодаря способности запасать корм на зиму, считается одним из самых оседлых видов врановых (Рустамов, 1954; Семенов-ТянШанский, Гилязов, 1991). Сведения по распространению кукши, ее местообитаниям, относительной численности во внегнездовой период и т. д. можно найти во многих сводках по птицам лесной зоны (Владимирская, 1948; Андреев Б., 1953, 1974, 1987; Воробьев, 1963; Реймерс, 1966; Гынгазов, Миловидов, 1977; Воронов, 1977; Кречмар и др., 1978, 1991; Сыроечковский, Рогачева, 1980; Мальчевский, Пукинский, 1983; Равкин, 1984; Рогачева, 1988; Нечаев, 1991; Блинов,

(C) Егоров Н. Н., Гермогенов Н. И., Секов А. Н., Лосоров А. В., 2019
1998; Вартапетов, 1998; Юдкин, 2002). По многим же аспектам популяционной биологии в российском секторе ареала кукша остается малоизученным видом. Прежде всего это касается популяционной биологии вида («резиденты», «иммигранты», третий - «пассивный»/«инертный» партнер пары), численность (плотность населения и гнездования) и ее динамика, половозрастная структура населения, филопатрия, натальная дисперсия и т. д., перечень публикаций по которым весьма ограничен (Андреев, 1980, 1982, 2006; Ларионов и др., 1980; Коханов, 1982; Гермогенов и др., 2002, 2013a, б, 2017; Бардин, Фетисов, 2016). Настоящее сообщение в определенной степени восполняет пробел в данной области исследований кукши в российской части ее ареала. 


\section{МАТЕРИАЛ И МЕТОДЫ}

Исследования количественного и качественного состава локальных популяций кукши проводили на мониторинговых площадках в различных подзонах якутской тайги в 1975-2015 гг. В северотаежной и лесотундровой подзонах комплексные учетные площадки располагались в лиственничниках (в том числе смешанных) и кустарниках в долинах рек Нижней Лены (19771984 гг.) - соответственно, пять площадок от 2 до 39 га и шесть - от 2 до 16 га, и р. Туостах в Верхоянье (1987-1990 гг.) - три площадки, соответственно, в 115 и 45 , и в 50 га.

Основные наблюдения за идентифицированными путем кольцевания птицами проводили в среднетаежных светлохвойных лесах близ г. Якутск $\left(62^{\circ} 01^{\prime}\right.$ с. ш., $123^{\circ} 49^{\prime}$ в. д.) на двух видовых, различных по ландшафтно-экологическим условиям обитания и гнездования, площадках (далее - площадка). Их картосхемы с нанесенными гнездами кукши приводятся в нашей работе (Гермогенов и др., 2017).

Площадка № 1 (61 $54^{\prime}$ с. ш., $129^{\circ} 55^{\prime}$ в. д.; 471 га, в том числе древесно-кустарниковых местообитаний - 389; 1987-1992, 2001, 2009 г.) располагалась в смешанном сосновом лесу правобережья р. Лена на 6-7-м км федеральной трассы «Лена». Площадка № $2\left(62^{\circ} 06^{\prime}\right.$ с. ш., $129^{\circ} 16^{\prime}$ в. д.; 1360.3 га, в том числе древесно-кустарниковых местообитаний - 980.0; 2009-2015 гг.) занимает участок тайги Лено-Вилюйского междуречья в районе 25 28-го км федеральной трассы «Вилюй», подвергнутый значительной фрагментации вследствие рубки и раскорчевки под ныне заброшенные пашни. Площадки отличались удаленностью от долины Лены, оказывающей известное отепляющее влияние на сопредельные территории, составом пород и степенью фрагментации древесно-кустарниковых местообитаний при полном отсутствии в них ели и слабой развитости подроста и подлеска. На площадке
№ 2 отлов, кольцевание и учеты кукш проводились в предгнездовой, гнездовой и постгнездовой периоды (март - май и середина августа - начало декабря), на площадке № 1 - преимущественно во время гнездования (конец марта - начало июня), на кратковременно выставляемых привадах (свиное сало) по общепринятым в орнитологии методам (Кольцевание..., 1976; Определение..., 1976; Данилов, 1986). Птенцов кольцевали в основном перед вылетом их из гнезда. Наблюдения за птицами вели в течение всего их гнездования (конец марта - начало июня).

Известно, что кукши способны размножаться уже на втором году жизни (Ekman, Griesser, 2016), но большинство из них начинает гнездиться в 3-4 года (Рустамов, 1954; Коханов, 1982; Ekman, Griesser, 2016). Поэтому возраст впервые отмечаемой на гнездовье особи (если она наблюдалась не более трех лет) оценивался как $3+$ года. Пол 55 птиц, отловленных на видовой площадке № 2 в 2009 г., установлен на основе ДНК-анализа их рулевых перьев, предоставленного Департаментом популяционной биологии университета Уппсала (Швеция) по совместному проекту «Географические изменения социальной структуры кукши» (2009-2011 гг.). В общей сложности на площадках стандартными металлическими и цветными кольцами помечено 375 кукш (в том числе 160 слетков), установлены места расположения 245 гнезд (от недостроенных до жилых): на площадке № 1 и вне ее, соответственно, 116 птиц, в том числе 61 слеток (19871992, 2009 г.) и 91 гнездо (с учетом найденных в районе будущей площадки в период с 1975 по 1986 г.), на площадке № 2 и в ее окрестностях - 259 птиц, в том числе 99 слетков и 157 гнезд. Результаты мониторинга птиц, персонализированных путем кольцевания на видовой площадке № 2 (99 птенцов-слетков из 120, 160 особей из 168 , впервые отмеченных на площадке), приведены в табл. 1.

Таблица 1. Материалы по мониторингу кукши на площадке № 2

Table 1. Materials on the Siberian Jay monitoring at Site 2

\begin{tabular}{|c|c|c|c|c|c|c|c|c|c|c|c|c|c|c|}
\hline \multirow{3}{*}{ Год } & \multicolumn{14}{|c|}{ Количество окольцованных птиц по годам и их последующая регистрация } \\
\hline & \multicolumn{2}{|c|}{2009} & \multicolumn{2}{|c|}{2010} & \multicolumn{2}{|c|}{2011} & \multicolumn{2}{|c|}{2012} & \multicolumn{2}{|c|}{2013} & \multicolumn{2}{|c|}{2014} & \multicolumn{2}{|c|}{2015} \\
\hline & 1 & 2 & 1 & 2 & 1 & 2 & 1 & 2 & 1 & 2 & 1 & 2 & 1 & 2 \\
\hline 2009 & $55^{*}$ & $?$ & 44 & $?$ & 41 & $?$ & 34 & $?$ & 26 & $?$ & 20 & $?$ & 13 & $?$ \\
\hline 2010 & & & 24 & $16(2)$ & 18 & 2 & 16 & 2 & 7 & 2 & 2 & 1 & 1 & 0 \\
\hline 2011 & & & & & 32 & $21(3)$ & 21 & 3 & 13 & 1 & 8 & 1 & 6 & 1 \\
\hline 2012 & & & & & & & 12 & $8(0)$ & 5 & 0 & 3 & 0 & 2 & 0 \\
\hline 2013 & & & & & & & & & 13 & $4(1)$ & 11 & 1 & 9 & 1 \\
\hline 2014 & & & & & & & & & & & 11 & $19(3)$ & 9 & 3 \\
\hline 2015 & & & & & & & & & & & & & 13 & $31(8)$ \\
\hline
\end{tabular}

*B том числе 2 погибшие птицы.

Примечание. 1 - птицы в возрасте около одного года и старше; 2 - местные слетки, в скобках - количество «осевших» на площадке слетков. Знак «?»- нет данных по гнездовым птенцам и слеткам. 
В работе использованы стандартные методы биологической статистики (Лакин, 1980; Гланц, 1999) с применением пакета анализа Microsoft ${ }^{\circledR}$ Excel и программы AtteStat v.12.5, а также ранговый корреляционный анализ Спирмена (r). Расчеты плотности населения и гнездования птиц на площадках выполняли с учетом их общей площади.

В разные годы в исследованиях участвовали сотрудники Института - к. б. н. Н. А. Находкин, И. Ю. Осипов, С. М. Слепцов (орнитологические наблюдения), к. б. н. Е. Г. Николин, к. б. н. А. П. Ефимова и Р. Р. Софронов (ботаническое описание площадок), а также орнитологи из университета Уппсала (Швеция) - Д. Барнабу и А. Панагакис. Всем им мы выражаем свою искреннюю признательность.

\section{РЕЗУЛЬТАТЫ И ИХ ОБСУЖДЕНИЕ}

Местообитания. Кукша населяет различные типы хвойных лесов. В бассейне Средней Лены (61-62 $2^{\circ}$ с. ш.) гнездится преимущественно по речным склонам и в таежных массивах междуречий, в том числе в кустарниках мелкодолинных ландшафтов. По горным рекам населяет склоны долин, прирусловые леса (верховья рр. Дянышка и Леписке в Западном Предверхоянье, $65^{\circ}$ с. ш.; долина р. Туостах в нижнем течении р. Адыча, Верхоянье, $68^{\circ}$ с. ш.). В пойме долины Нижней Лены от района Сорока Островов $\left(64^{\circ} 30^{\prime}\right.$ с. ш.) до устья р. Бесюке $\left(70^{\circ} 30^{\prime}\right.$ с. ш.) кукши на гнездовье не обнаружены (Гермогенов и др., 1997), но замечены в разорении гнезд рябинника, чечетки и белой трясогузки (район устья р. Муна, $68^{\circ}$ с. ш.).

В зависимости от ландшафтно-экологических условий обитания в гнездоразмещении птиц отмечались разные предпочтения. Так, на площадке № 1, где преобладали боры и сосноволиственничные насаждения, кукши устраивали гнезда $(\mathrm{n}=91)$ преимущественно на соснах $(62.6 \%)$ и лиственницах (33.0); на площадке № 2, поросшей по краям многочисленных здесь болотин, аласов и других открытых пространств кустарниками и лиственничниками $(\mathrm{n}=144),-$ на ивах (56.9) и лиственницах (35.4) (Гермогенов и др., 2017).
Численность и плотность населения (общая и гнездовая) птиц подвержены пространственновременной изменчивости. На площадке № 1, pacположенной в непосредственной близости от p. Лена, под отепляющим влиянием реки формируется более благоприятный для зимовки и воспроизводства вида микроклимат, плотность гнездования птиц составляла в среднем 1.8 (табл. 2) против 1.4 пары/км² на менее комфортной в этом отношении площадке № 2, расположенной на Лено-Вилюйском водоразделе (табл. 3). Различия сохраняются и в случае, если в расчетах учитывать показатели «облесенности» площадок, по которым они существенно разнятся: на площадке № 1 древесно-кустарниковые местообитания составляли 82.6 , на площадке № $2-72.0 \%$.

В подходящих местообитаниях северной тайги региона кукша гнездится с близкой плотностью, но не так регулярно, как в центральноякутской. Так, на учетных комплексных площадках в долине р. Туостах (Верхоянье) в 1987-1990 гг. она составляла 0.9 (надпойменный листвяг: 115 га, 33.3\% встречаемости птиц по годам) -2.2 (смешанный листвяг в островной пойме, соответственно, 45 га и 75.0\%) пары $/$ км$^{2}$. Эти данные свидетельствуют об ослаблении у северных популяций вида «территориального консерватизма», вероятно, вследствие непредсказуемости условий гнездования по годам и их сезонной неустойчивости на фоне долгой зимовки с продолжительными периодами стояния сверхнизких температур, часто возникающей сезонной бескормицы, которые негативно влияют на рождаемость и выживаемость птиц.

Временные изменения численности птиц межгодовые и сезонные, более значительны (см. табл. 2, 3; рис. 1, табл. 4). На репрезентативной для изучения механизмов регуляции численности населения площадке № 2, на которой отмечалось регулярное, хотя и незначительное, пополнение его птенцами местного приплода (Гермогенов и др., 2017), общая численность птиц в 2010 г. выросла, по сравнению с 2009 г., в 1.3, в 2011 г. - в 1.8 раза (см. рис. 1 , табл. 3). За последовавшим затем падением, не столь интенсивным, как на подъеме, она не опустилась ниже минимального уровня, отмеченного в 2009 г.

\section{Таблица 2. Динамика репродуктивного населения кукши на площадке № 1}

Table 2. Dynamics of the Siberian Jay reproductive population at Site 1

\begin{tabular}{|l|c|c|c|c|c|c|}
\hline \multicolumn{1}{|c|}{ Параметры населения } & 1987 г. & 1988 г. & 1989 г. & 1990 г. & 1991 г. & 1992 г. \\
\hline Кол-во гнездящихся пар (гнезд): & $10(11)$ & $11(11)$ & $5(5)$ & $9(11)$ & $10(13)$ & $6(7)$ \\
резиденты, \% & $?$ & $2(18.2)$ & $4(80.0)$ & $4(44.5)$ & $6(60.0)$ & $5(83.3)$ \\
иммигранты, \% & $?$ & $9(81.8)$ & $1(20.0)$ & $5(55.5)$ & $4(40.0)$ & $1(16.7)$ \\
\hline Плотность гнездования, пар/ км ${ }^{2}$ & 2.1 & 2.3 & 1.1 & 1.9 & 2.1 & 1.3 \\
\hline
\end{tabular}

Примечание. Здесь и в табл. 3 знак «?» - нет данных по статусу птиц. 
Таблица 3. Динамика населения кукши на площадке № 2

Table 3. Dynamics of the Siberian Jay population at Site 2

\begin{tabular}{|l|c|c|c|c|c|c|c|}
\hline \multicolumn{1}{|c|}{ Параметры } & 2009 г. & 2010 г. & 2011 г. & 2012 г. & 2013 г. & 2014 г. & 2015 г. \\
\hline Численность птиц, ос.: & 57 & 76 & 98 & 88 & 68 & 63 & 68 \\
резидентов*, \% & $?$ & $46(60.5)$ & $64(65.3)$ & $76(86.4)$ & $55(80.9)$ & $51(81.0)$ & $54(79.4)$ \\
иммигрантов*, \% & $?$ & $30(39.5)$ & $34(34.7)$ & $12(13.6)$ & $13(19.1)$ & $12(19.0)$ & $14(20.6)$ \\
\hline Кол-во гнездящихся пар (гнезд) & $16 / 56.1$ & $15 /$ & $18 /$ & $18 /$ & $19 /$ & $21 /$ & $24 /$ \\
В т. ч. состоящих из пар: & $(16)$ & $39.5(16)$ & $36.7(23)$ & $40.9(22)$ & $55.9(28)$ & $66.7(26)$ & $70.6(26)$ \\
«резидентов», \% & $?$ & $9(60.0)$ & $11(61.1)$ & $13(72.2)$ & $14(73.7)$ & $17(80.9)$ & $14(58.4)$ \\
«иммигрантов», \% & $?$ & $3(20.0)$ & - & - & - & - & - \\
«резидент»+ «иммигрант», \% & $?$ & $2(13.3)$ & $2(11.1)$ & - & $1(5.3)$ & $1(4.8)$ & $2(8.3)$ \\
«резидент»+ неидентифицирован- & & & & & & \\
ный партнер, \% & $?$ & - & $2(11.1)$ & $1(5.6)$ & - & $1(4.8)$ & $3(12.5)$ \\
«иммигрант»+ неидентифицирован- & & & & & & - & - \\
ный партнер, \% & $?$ & - & $1(5.6)$ & - & - & - \\
неидентифицированных птиц, \% & $?$ & $1(6.7)$ & $2(11.1)$ & $4(22.2)$ & $4(21.0)$ & $2(9.5)$ & $5(20.8)$ \\
\hline Доля гнездящихся птиц, \% & 56.1 & 39.5 & 36.7 & 40.9 & 55.9 & 66.7 & 70.6 \\
\hline Плотность населения, ос./ км ${ }^{2}$ & 4.2 & 5.4 & 7.2 & 6.5 & 5.0 & 4.6 & 5.0 \\
\hline Плотность гнездования, пар/км ${ }^{2}$ & 1.2 & 1.1 & 1.3 & 1.3 & 1.4 & 1.5 & 1.8 \\
\hline
\end{tabular}

*В том числе попавшие в осенние учеты местные слетки («автохтоны»), не идентифицированные «резиденты» и, вероятно, «иммигранты». Прочерк - пары с подобным сочетанием партнеров отсутствуют.

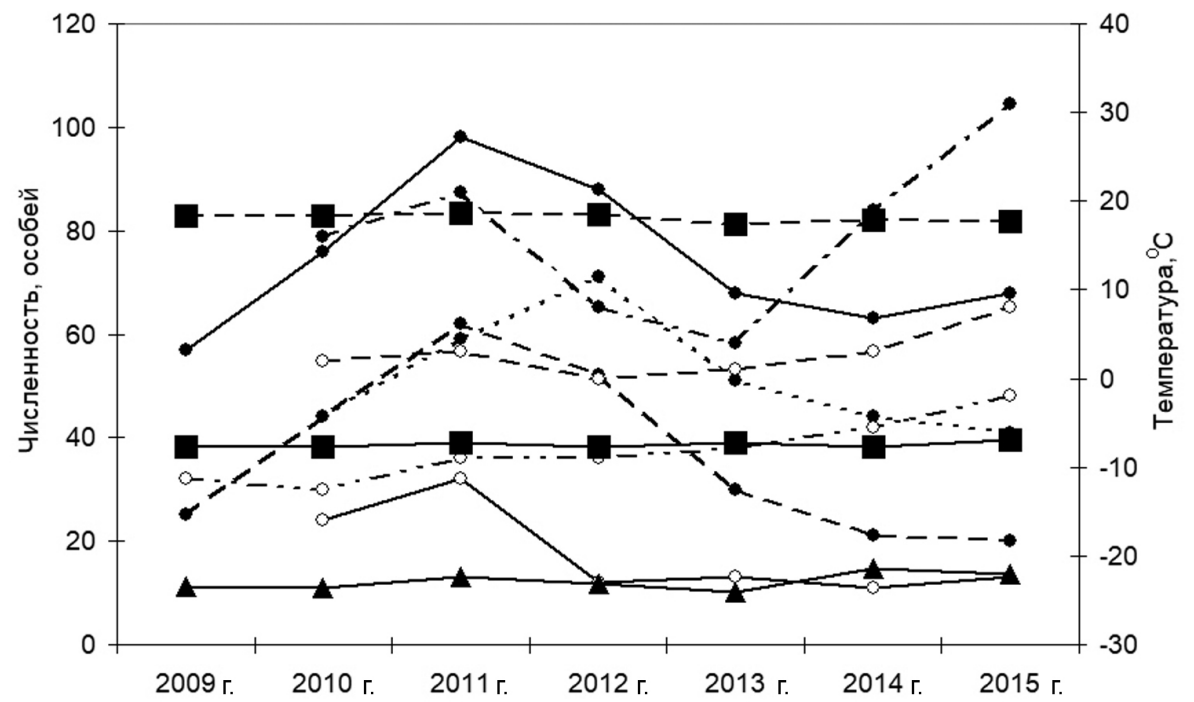

Pис. 1. Динамика численности населения и отдельных групп птиц на площадке № 2 и некоторых средних параметров температуры воздуха. Численность: $\longrightarrow-$ общая, $-\boldsymbol{- \bullet -}-$ «резидентов», - - - «иммигрантов», - - - гнездящихся птиц, - - - - не гнездящихся птиц, $-\bullet-$ - сеголетков, - - - - осевших сеголетков. Температура: $\square-$ среднегодовая, $-\mathbf{-}-$ - среднелетняя, $\square-$ среднезимняя

Fig. 1. Size dynamics of the bird population and certain groups at Site 2 and of some average parameters of the air temperature. Size: $-\longrightarrow$ - total, $--\bullet-$ "residents", $-\infty-$ - "immigrants", $-\circ-$ nesting birds,

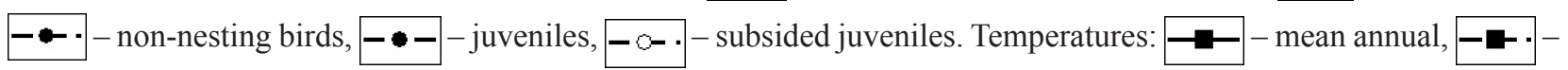
average summer, $\longrightarrow-$ - average winter

Снижение численности птиц вначале было вызвано почти 3-кратным сокращением их притока извне, а затем, после зимы 2012/13 г., - таким же по масштабам сокращением числа птиц, ведущих на территории оседлый образ жизни. Можно полагать, что причиной тому послужило похолодание (см. рис. 1), вызвавшее, вероятно, повышение зимней элиминации птиц как на площадке, так и на сопредельных территориях.

Максимум численности населения птиц пришелся на 2011 г. Это было обусловлено высокой сохранностью птиц зимой 2009/10 г. (из 
Таблица 4. Сезонная динамика численности населения кукши на площадке № 2

Table 4. Seasonal population dynamics of the Siberian Jay at Site 2

\begin{tabular}{|c|c|c|c|c|c|c|}
\hline & & & & I и се & & \\
\hline & раметры населения & 2009 & & & & \\
\hline & & II* & $I^{* *}$ & II & I & II \\
\hline Численность птиц, ос. & & 57 & 43 & 67 & 61 & 79 \\
\hline В том числе в гнездив- & всего & 26 & & & & \\
\hline шихся парах & \% от численности по сезонам & 45.6 & 69.8 & 44.8 & 59.0 & 45.6 \\
\hline Плотность населения, о & $/ \mathrm{KM}^{2}$ & 4.2 & 3.2 & 4.9 & 4.9 & 5.8 \\
\hline
\end{tabular}

*Середина августа - начало декабря.

**Март - май.

57 птиц благополучно перезимовало 46, или $80.7 \%$ ), приращиванием населения за счет значительного числа осевших на площадке в зиму 2010/11 г. птиц инорайонного происхождения 18 из 30 ос. (см. табл. 1, 3) и, главным образом, новым их притоком в 2011 г., наивысшим за все годы исследований - 34 ос. (см. табл. 3). Три последних года наблюдений население птиц площадки находилось в относительно стабильном состоянии.

При статистической проверке связи численности различных социальных групп птиц с некоторыми показателями температуры воздуха значимых зависимостей (корреляций) не обнаружено. Тем не менее на площадке № 1 выявлена высокая (по шкале Чеддока) обратная теснота связи числа гнездящихся пар от средней зимней температуры воздуха ( $\mathrm{r}=-0.729)$, на площадке № 2 (см. рис. 1) - умеренная зависимость в этой группе птиц как от среднезимней $(\mathrm{r}=0.598)$, так и от среднегодовой $(\mathrm{r}=0.643)$ и среднелетней $(\mathrm{r}=-0.545)$ температур воздуха.

В отличие от динамичных межгодовых, вероятно циклических, колебаний численности населения изменения числа ежегодно участвующих в размножении птиц в годы наблюдений носили прямолинейный характер с тенденцией к росту (см. рис. 1). Они соответствовали трендам температурных параметров потепления климата. Вероятно, наблюдаемые климатические изменения, в целом благоприятные для размножения, особенно таких раногнездящихся видов, как кукша, способствуют более полной реализации их репродуктивного потенциала, благодаря появлению или наличию даже в оптимальных местообитаниях свободных для гнездования экологических ниш.

Динамичность населению придают не участвующие в воспроизводстве птицы - от 29.4 (2015 г.) до 63.3 (2011), в среднем $49.4 \%$ от общего состава (см. табл. 3, рис. 1), состоящие в среднем на 1/3 из птиц, впервые временно проникших на площадку извне (30.0-46.8, в среднем $32.3 \%$ ), представляющих собой наиболее «подвижную» часть населения. Они отличаются не только слабыми территориальными связями и повышенной склонностью к эмиграции, при отсутствии свободных экологических (гнездовых) ниш, но и повышенной смертностью в случае зимовки на новой для них территории, не обеспеченной для этого достаточным количеством собственных запасов кормов. Зимой в районе г. Якутск нами отмечена гибель 7 птиц (в том числе 5 окольцованных). Две из них были найдены замерзшими (одна - на кусте, на который она, вероятно, упала с дерева, другая - на ветке, повисшей головой вниз), одна была застрелена, три попали в капкан и одна (самка в возрасте 7+ лет) обнаружена мертвой под гнездом с двумя замерзшими на стадии вылупления яйцами и двумя однодневными птенцами 27 апреля 2013 г.

Численность кукш наиболее низка в пред- и гнездовой периоды (март - май), что может объясняться эмиграций, в основном предзимней, части населения (преимущественно не осевших на территории площадки осенних вселенцев) и повышенной зимней элиминацией птиц, и высока в поствыводковый период - в августе - начале декабря, когда численность населения вида возрастает в 1.3-1.6 раза вследствие происходящей преимущественно в это время иммиграции птиц (см. табл. 4).

Роль местного приплода в пополнении численности населения в конце года, наблюдаемом только на площадке № 2, и то в небольшом количестве и не ежегодно, незначительна при сопоставлении с таковой птиц, ежегодно прибывающих извне и впоследствии частично оседающих на ее территории (см. рис. 1). На более чем вдвое меньшей площадке № 1 все гнездовые птенцы после слета $(\mathrm{n}=61)$ в ее пределах и в окрестностях более не регистрировались. Возможно, что это объясняется отчасти нерепрезентативностью для демографических исследований размеров территории последней, возможно, различиями в интенсивности воспроизводства и т. д. Так, при близкой плотности гнездования птиц на площадках: № $1-1.1-2.3$ (см. табл. 2) и № $2-1.1-1.8$ пары/км² (см. табл. 3), свидетельствующей об от- 
носительной равноценности условий их обитания, эффективность размножения (число яиц в полных кладках/ число слетков) на первой из них в среднем оказалась несколько ниже - 34.0\% (от 0 до 57.1), чем на второй, - соответственно 43.5\% (от 20.5 до 70.0) (Гермогенов и др., 2017).

Отмечаемые демографические особенности вида в целом определяются, на наш взгляд, в основном относительно низкой эффективностью размножения птиц и малой сохранностью на территории их птенцов. Так, доля успешных гнезд составляет (с учетом уже пустующих, но с признаками разорения) в среднем $33.1 \%$ (n = 157): на площадке № $1(\mathrm{n}=59)-28.8$ при вариациях от 0 до $50.0 \%$, на площадке № $2(\mathrm{n}=98)$ - соответственно, 35.7 и 18.8-53.8 (Гермогенов и др., 2017). На площадке № 2 в 2010-2015 гг. на зиму осело 17 из 99 окольцованных слетков (17.2\%): ежегодно от 0 (2012 г.) до 25.8 (2015 г.), в среднем - 17.2\%. Они составили 0-15.1, в среднем 4.1\% от идентифицированной части населения площадки $(\mathrm{n}=414)$. Судьба остальных птиц (n = 82), как и слетков на площадке № 1, не установлена. Причина столь низкой филопатрии - интенсивная дисперсия сеголетков. Она начинается вскоре после их вылета из гнезда, в результате острого соперничества между одновыводковыми птенцами, отмечаемого еще на стадии их гнездового развития (Ekman, Griesser, 2016).

Вместе с тем в отдельные годы успех размножения может быть весьма значительным. На площадке № 2 максимальное количествоо вылетевших птенцов, включая не окольцованных, в 2011 г. достигало 28 ос., в 2015 г. - 34, или, соответственно, 28.6-50.0\% от общей численности населения (Гермогенов и др., 2017). По данным кольцевания, в эти годы доля слетков по отношению к идентифицированной части населения составляла 23.1 (2011 г.) - 58.5 (2015 г.), в среднем $37.4 \%$, тогда как в остальные не достигала и ее четверти (6.2-23.5, составляя в среднем $13.0 \%$ ). На зиму оседало почти вдвое больше слетков: $19.7 \%$ (14.3-25.8) против 10.7 (0-25.0).

Вероятно, определенная часть местного приплода гибнет, выжившая - рассеивается, вытесняемая одновыводковыми особями-доминантами, заполняя свободные экологические ниши на других территориях обитания популяции и, тем самым, что не менее важно, способствуя поддержанию ее генетического разнообразия. Можно полагать, что подобные периодически наблюдаемые локальные «всплески» рождаемости и лежат в основе механизма саморегуляции численности популяции.

Структура населения. В зависимости от характера использования птицами территории в населении вида можно выделить две категории особей. Это «резиденты» - птицы местного («авто- хтоны») и инорайонного происхождения, ведущие оседлый образ жизни, и «иммигранты»птицы, ежегодно впервые регистрируемые (преимущественно осенью или поздней зимой) и кратковременно пребывающие на территории (не более полугода, нередко с гнездованием).

«Резиденты». Одни исследователи считают, что на зиму часть кукш откочевывает в более южные районы (Владимирская, 1948; Blomgren, 1971; Андреев, 1980;), другие - что в это время у них возрастает территория обитания (Blomgren, 1971). По С. Крампу и К. М. Перринсу, в Фенноскандинавии птицы становятся оседлыми после натальной дисперсии, в то время как в Сибири перемещения птиц наблюдаются и в зимнее время (Cramp, Perrins, 1994), что отчасти подтверждается наблюдениями А. В. Андреева по р. Колыма (1980). В Мурманской области широких перекочевок птиц не отмечают. Расселение молодых особей происходит на следующий год дважды в конце зимы - весной и в конце осени - начале зимы (Коханов, 1982).

По нашим данным, в условиях средней тайги, с ее достаточно продолжительным зимним световым режимом, «резиденты» держатся на территориях обитания постоянно. Кочевки, определяемые перемещениями нетерриториальных молодых и взрослых птиц, носят локальный характер и происходят в относительно теплые и короткие периоды «межсезонья»: конец зимы - весна, осень - начало зимы. В зимний период птицы ведут оседлый образ жизни. В середине зимы они активны не более 3.5 ч в сутки (Андреев, 2006). Под местами их постоянных ночевок мы наблюдали столбики помета высотой до 0.5 м.

На площадке № 2 «резиденты» устойчиво доминировали в составе населения - 60.5-86.4\% его численности (см. табл. 3, рис. 1). Причем тренды динамики их численности в отдельные годы не совпадали с таковыми населения в целом и «иммигрантов» в частности.

«Резиденты» формировали здесь большую часть гнездовых пар (в среднем 67.8\%), частично - в партнерстве с «иммигрантами» или неустановленными особями - еще от 5.3 (2013 г.) до $22.2 \%$ (2011 г.) (см. рис. 1). В среднем на их долю приходится $74.3 \%$ размножающихся особей. На меньшей по размерам площадке № 1 доля «резидентов» среди гнездящихся пар была не столь высокой - в среднем 51.2\% (см. табл. 2). Таким образом, «резиденты» определяют, ввиду оседлого образа жизни и особенностей динамики численности, пространственно-временную устойчивость населения.

Сохранность на площадке № 2 представителей всех групп «резидентов», выделяемых в зависимости от года их идентификации (на основе кольцевания), снижается ежегодно в основном 
однотипно и примерно с одинаковой скоростью (рис. 2).

Исключение составили группа птиц, идентифицированных как «резиденты» в 2011 г. Из-за резкого падения их численности в 2012-2014 гг., в 2015 г., на пятый год наблюдения, из 18 ос. сохранилась лишь одна (5.6\%). Наиболее высокая сохранность отмечена у птиц, являющихся «резидентами» с 2010 г. $(\mathrm{n}=44)$. Но если численность их снижалась в 2011-2014 гг. по отношению к первоначальной по подобию среднестатистической, то, при сопоставлении результатов их встречаемости по отношению к предыдущему году, гораздо менее интенсивно. А в 2014 г. сохранность птиц в этой группе «резидентов» незначительно превышала таковую в 2013 г. (рис. 3).

Численность птиц после первой зимовки в качестве «резидентов» $(\mathrm{n}=99)$ падает в среднем до $82.8 \%$ от первоначальной (при вариациях 60.0-93.2\%; 5 групп), второй $(\mathrm{n}=88)$ - до 57.9 (38.1-77.3; 4 группы), третьей $(\mathrm{n}=83)$ - до 41.0 (11.1-59.1; 3 группы), четвертой $(\mathrm{n}=62)$ - до 33.9 (5.6-45.4; 2 группы), пятой $(\mathrm{n}=44)$ - до 29.5\% (1 группа).

Гнездование (особенно успешное) - важное условие укрепления связей птиц с территорией, формирования у них «гнездового консерватизма». Пропуски в размножении у территориальных репродуктивных «пар-резидентов» не отмечаются. В случае гибели одной из птиц пары оставшаяся способна не только сохранить за со- бой занятый участок, но и в очередной раз загнездиться на нем с новым партнером, в том числе с «иммигрантом».

Исчезновение пары с площадок, как и одного из партнеров, вне зависимости от итогов предшествующего ему размножения, вероятнее всего, обусловлено их элиминацией. Тем не менее на площадке № 1 две гнездящиеся пары - одна «резидент», вторая, образованная «иммигрантами», терялись из нашего поля зрения на год. «Пара-резидент» № 13 (1987-1992 гг.) на год (1990 г.) исчезала из поля зрения, не встречаясь на занимаемой территории и в пределах площадки (1990 г.). Так и не осевшая на территории «пара-иммигрант» № 14 регистрировалась на площадке дважды, причем на гнездовье: первый раз в 1988 г., второй (после годового отсутствия на площадке) - в 1990 г.

Смена «резидентами» гнездового участка отмечалась на площадке № 1 многократно, но в основном пределах ее территории. Наблюдения за 10 парами показывают, что преданность гнездовому участку прослеживается у них в 78.3\% случаев гнездования ( $\mathrm{n}=23)$. Смена участка наблюдалась у одной из пар дважды: на четвертом и пятом году, у остальных - после первого $(\mathrm{n}=2)$ и второго (10) сезонов гнездования. На площадке № 2 это зарегистрировано у отдельных птиц из распавшихся пар при их гнездовании с новым партнером. В одном случае это был самец, занявший с новой самкой соседний с предыдущим участок, в другом - самка, которая поочередно гнез-

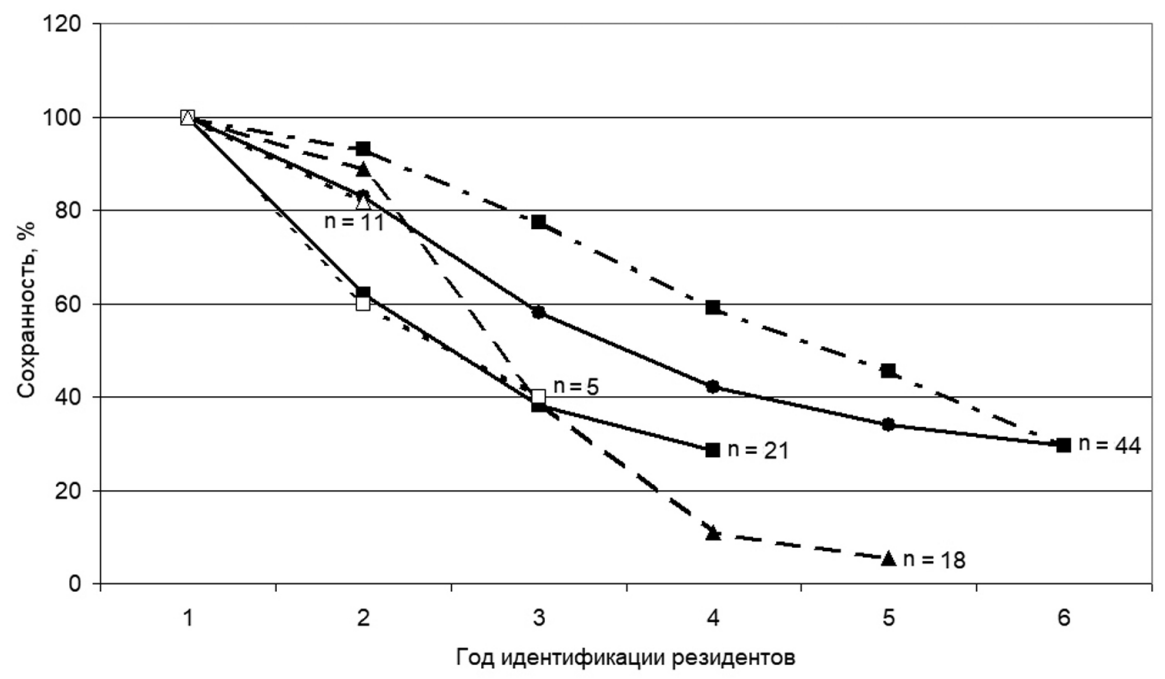

Рис. 2. Сохранность (\%) на площадке № 2 птиц различных групп «резидентов», выделяемых по годам их

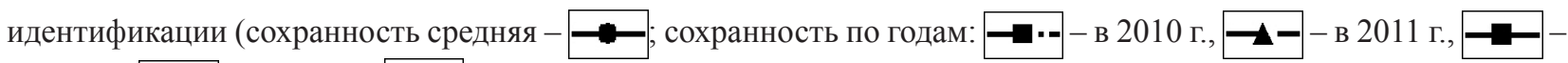
в 2012 г., - $\square$ - в 2013 г., $-\triangle \mathbf{-}-$ в 2014 г.)

Fig. 2. Preservation (\%) of birds of various "resident" groups at Site 2, by the years of their identification (ave-

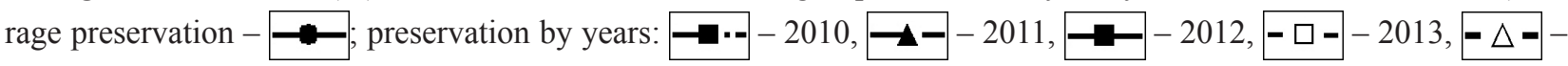
2014) 


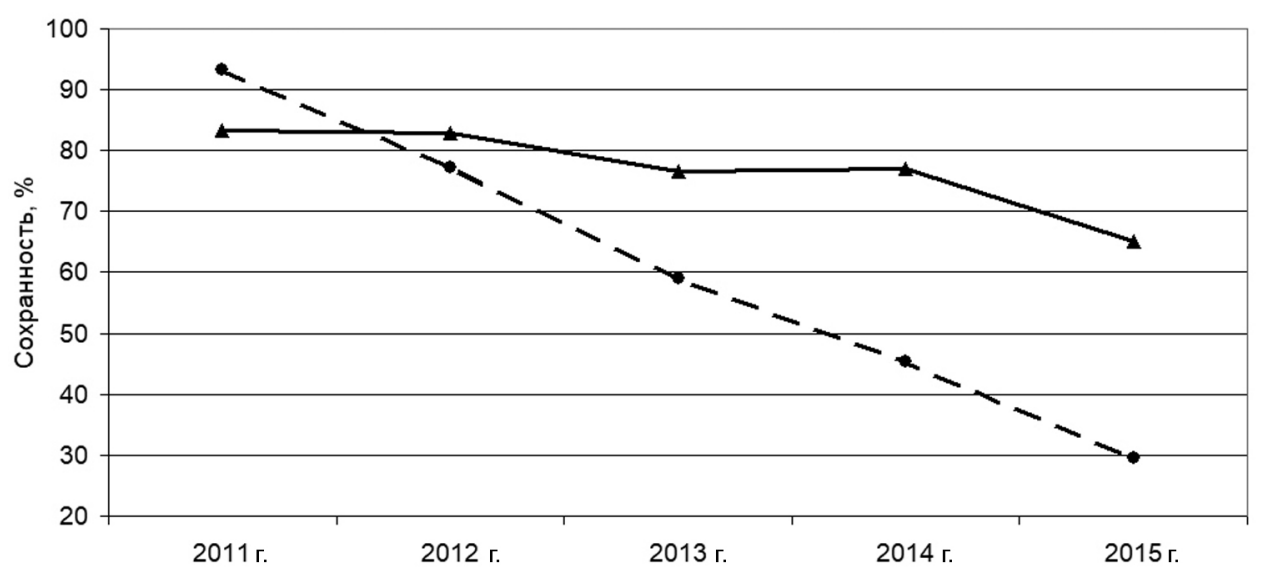

Pис. 3. Сохранность птиц (\%), являющихся «резидентами» на площадке № 2 с 2010 г., по отношению к первоначальному составу $(-\bullet-)$ и к предыдущему году $(\square)$

Fig. 3. Preservation (\%) of "residents" at Site 2 since 2010 in relation to the original composition

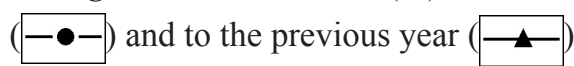

дилась с разными партнерами на четырех также соседних участках. Наиболее вероятной причиной смены неоднократно размножавшимися кукшами репродуктивных участков на площадке № 1 является предшествующее неудачное гнездование $-80.0 \%$ пар $(\mathrm{n}=5)$ против $62.5(\mathrm{n}=16)$ у оставшихся на прежнем месте (Гермогенов и др., 2002).

Отсутствие «возвратов» колец от «резидентов» с удаленных от площадок территорий не позволяет говорить о наличии у них дальней гнездовой дисперсии (фактически, эмиграции). Все достаточно немногочисленные случаи отстрела и попадания в капканы окольцованных «птицрезидентов» зафиксированы вблизи их гнездовых участков, не далее 1.5 км от места расположения их последнего гнезда.

Как отмечалось, потери «резидентов» - постоянного контингента населения, восполнялись на площадке № 2 местными сеголетками не ежегодно: в 2012 г. из 8 слетков к концу года не сохранилось ни одного, и в небольшом количестве: в 2010-2011 и 2013-2014 гг. на зиму оставались и успешно перезимовывали 1-3, в среднем 2.2 птенца $(\mathrm{n}=17)$. В среднем доля этих сеголетков составляла, по отношению к численности идентифицированной в эти годы части населения (n= 414), всего 5.1\%. Большинство птенцов исчезает (эмигрируют или погибают) к осени - началу зимы (см. табл. 1). В основе механизма дисперсии, как известно, лежит острая внутривыводковая конкуренция (Ekman, Griesser, 2016).

К концу 2015 г. на этой площадке сохранилось 5 ранее окольцованных птенцами птиц в возрасте $1.5(\mathrm{n}=3), 2.5(\mathrm{n}=1)$ и $4.5(\mathrm{n}=1)$ лет, на зиму осело 8 сеголетков из 31 слетка из 8 гнезд. В период с 2013 по 2015 г. исчезли четыре осевших на территории слетками птицы: две - на третьем, одна - на пятом и одна - на шестом году жизни.

В Мурманской области подкармливаемые родителями птенцы-слетки (иногда до конца августа) обычно отмечаются с ними до весны следующего года (Коханов, 1982). По Швеции известно, что с родителями на зиму остается один, крайне редко два птенца. В этом случае происходит задержка их дисперсии и начала репродуктивной жизни (Ekman et al., 1994). Таким образом, молодые птицы могут покидать родителей и их участок и в годовалом, и в более позднем возрасте (Коханов, 1982). По нашим данным, часть птенцов уже осенью обретает самостоятельность и способна формировать пары с другими птицами.

«Иммигранты» появляются на площадках ежегодно в периоды межсезонья - в конце зимы - весной и осенью - в начале зимы. На площадке № 1 в наибольшем количестве они отмечены во второй половине марта 1988 г.: 22 птицы, из которых загнездились 18 ос. (9 пар). На площадке № 2 «иммигранты» составляли от 13.6 (2012 г.) до 37.8 (2010 г.), в среднем 24.6\% численности населения. Среди них птицы, не участвующие в воспроизводстве, отмечались только в 2012 г. (см. рис. 1). В остальные годы доля гнездящихся «иммигрантов» колебалась от 7.7 (2013 г.) до 35.7 (1915 г.), составляя в среднем $13.3 \%$ от их численности, и от 2.6 (2013 г.) до 26.7 (2010 г.), в среднем 9.6\% от общей численности гнездящихся птиц.

Наибольший приток «иммигрантов» наблюдался на пике их численности в 2010 и 2011 г. - соответственно, 39.5-34.7\% от общей численности населения (см. табл. 3, рис. 1; табл. 5). 


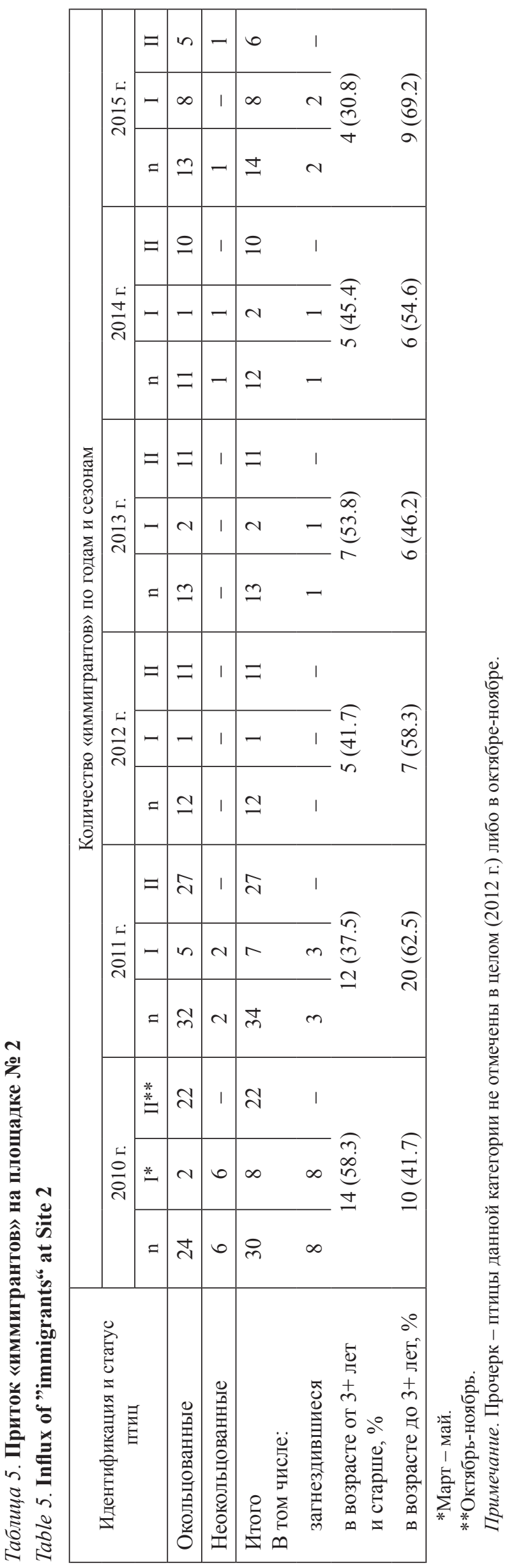


Это способствовало тому, что в эти годы на площадке численность птиц имела высшие показатели за все время наблюдений (см. табл. 3, рис. 1). При этом отмечался и рост общей численности гнездящихся птиц, формируемой исключительно «резидентами». Участие в воспроизводстве «иммигрантов» определялось их возрастной структурой: в первый год подъема численности, когда преобладали птицы репродуктивного возраста - от $3+$ лет и старше $(58.3 \%)$, загнездилось 8 ос. $(28.6 \%$ от общего их числа и 26.7 - от общего числа гнездящихся птиц), во второй, при доминировании неполовозрелых птиц (62.5\%) 5 (соответственно, 14.7 и 13.9\%). Но независимо от этого в годы и высокой, и низкой численности «иммигрантов» оно было несопоставимо меньшим такового «резидентов» и в основном не влияло на динамику гнездящихся птиц.

В последующие годы доля «иммигрантов» в населении стабилизировалась на уровне 13.6-20.6\% с преобладанием птиц, в основном прикочевавших в осенне-раннезимнее время (см. табл. 5). В их составе присутствовали как особи и пары репродуктивного возраста, так и неполовозрелые птицы (в возрасте $\leq 2+$ года), которые в целом несколько преобладали над первыми. «Иммигранты» в основном гнездились на площадке № 2 в составе смешанных пар (см. табл. 4). К зиме или в течение следующего года эти птицы, независимо от характера пребывания, либо исчезали и более не регистрировались, либо оседали, приобретая статус «резидентов». При росте численности населения на площадке сохранялось от 25.0 до $64.3 \%$ «иммигрантов».

На площадке № 1, на которой учитывались только участвующие в размножении «иммигранты», вероятность закрепления 19 репродуктивных пар из их позднезимних притоков путем гнездования составила в среднем $31.6 \%$ (Гермогенов и др., 2002). Их исчезновению предшествовала попытка неудачного размножения (9 пар из $10)$ и распад пар из-за гибели самок $(\mathrm{n}=2)$. Численность «иммигрантов» на площадке № 2 (за исключением 2013 г.) менялась синхронно с таковой населения в целом, придавая ему дополнительную динамичность (см. рис. 1).

Возрастной и половой состав. На площадке № 2 осенью 2009 г. среди 55 окольцованных птиц (96.5\% населения) с незначительной раз- ницей преобладали неполовозрелые особи $56.4 \%$ (табл. 6). В последующие два года в группе «взрослых» птиц ежегодно недосчитывалось по $16.7 \%$ ос. от первоначального состава, среди условно «молодых» птиц, соответственно, 41.9 и $6.5 \%$. На третьем году наблюдений эти различия значительно нивелировались (соответственно, 33.3 и 48.4\%), поскольку «молодые» птицы с возрастом адаптировались к самостоятельной жизни, что положительно отразилось на их выживаемости. В группе «взрослых» птиц вначале отмечалось небольшое преобладание самок, «молодых», с той же разницей - самцов.

В дальнейшем соотношение полов в первой возрастной группе выравнялось, а во второй преобладание самцов сохранилось. В 2012 г. от отмечаемого в 2009 г. состава сохранилось $56.4 \%$ птиц (31 ос.), в 2013 г. - 41.8 (23), в 2014 г. -34.5 (19) и в 2015 г. $-23.6 \%$ (13 ос.). При этом из 28 самцов сохранилось, соответственно, 18 (64.3\%), $12(42.9 \%), 10(35.7 \%)$ и $8(28.6 \%)$, из 27 самок $13(48.2 \%), 11(40.7 \%), 9(33.3 \%)$ и $5(18.5 \%)$.

Основу населения птиц площадки № 2 (без учета приплода), как правило, составляют взрослые особи ( $\geq 3+$ лет) - от 70.6\% (2010 г.) и более, в среднем 79.5 (рис. 4). Независимо от возраста птиц и состояния их численности, с учетом присутствия в обеих группах значительного числа птиц с неопределенным полом, в целом соотношение самок и самцов примерно одинаково или с небольшим преобладанием самцов.

На конец 2015 г. возраст населяющих площадку птиц варьировал от 1+ до 9+ лет (табл. 7). Около половины птиц населения составляли особи в возрасте $3+(17 \%), 5+(15.1 \%)$ и $7+$ $(17 \%)$ лет. Зарегистрированный у особей местного приплода с 2010 по 2014 г. возраст соответствовал предельно возможному - 4 года 7 мес. С учетом рожденных и осевших на площадке птиц (табл. 8) доля молодых особей в населении возрастает до 31.4 (2010 г.) - 35.4\% (2015 г.).

Динамика численности птиц большинства выделяемых возрастных групп по годам характеризуется чередованием резких коротких периодов подъемов и продолжительных ее при доминировании $3+\ldots 8+$-летних особей.

В 2010-2015 гг. из 34 репродуктивных пар 6 гнездились один сезон (в том числе 4-в 2015 г.),

Таблица 6. Сохранность кукш, окольцованных на площадке № 2 в 2009 г., с учетом их возраста и пола Table 6. Preservation of Siberian jays ringed at Site 2 in the autumn of 2009, with due account of their age and sex

\begin{tabular}{|c|c|c|c|c|c|c|c|}
\hline \multirow{2}{*}{ Возрастная группа } & \multirow{2}{*}{ Пол } & \multicolumn{6}{|c|}{ Количество птиц по годам, по ноябрь включительно, \% } \\
\hline & & \multicolumn{2}{|c|}{2009 г. } & \multicolumn{2}{|c|}{2010 г. } & \multicolumn{2}{|c|}{$2011 \Gamma$} \\
\hline \multirow{2}{*}{ Птицы от 3+ лет и старше } & $q$ & $13(54.2)$ & \multirow{2}{*}{$24(43.6)$} & $10(50.0)$ & \multirow{2}{*}{$20(83.3)$} & $8(50.0)$ & \multirow{2}{*}{$16(66.7)$} \\
\hline & o & $11(45.8)$ & & $10(50.0)$ & & $8(50.0)$ & \\
\hline \multirow{2}{*}{ Птицы до 3+ лет } & $q$ & $14(45.2)$ & \multirow{2}{*}{$31(56.4)$} & $7(38.9)$ & \multirow{2}{*}{$18(58.1)$} & $7(43.8)$ & \multirow{2}{*}{$16(51.6)$} \\
\hline & $\hat{0}$ & $17(54.8)$ & & $11(61.1)$ & & $9(56.2)$ & \\
\hline
\end{tabular}




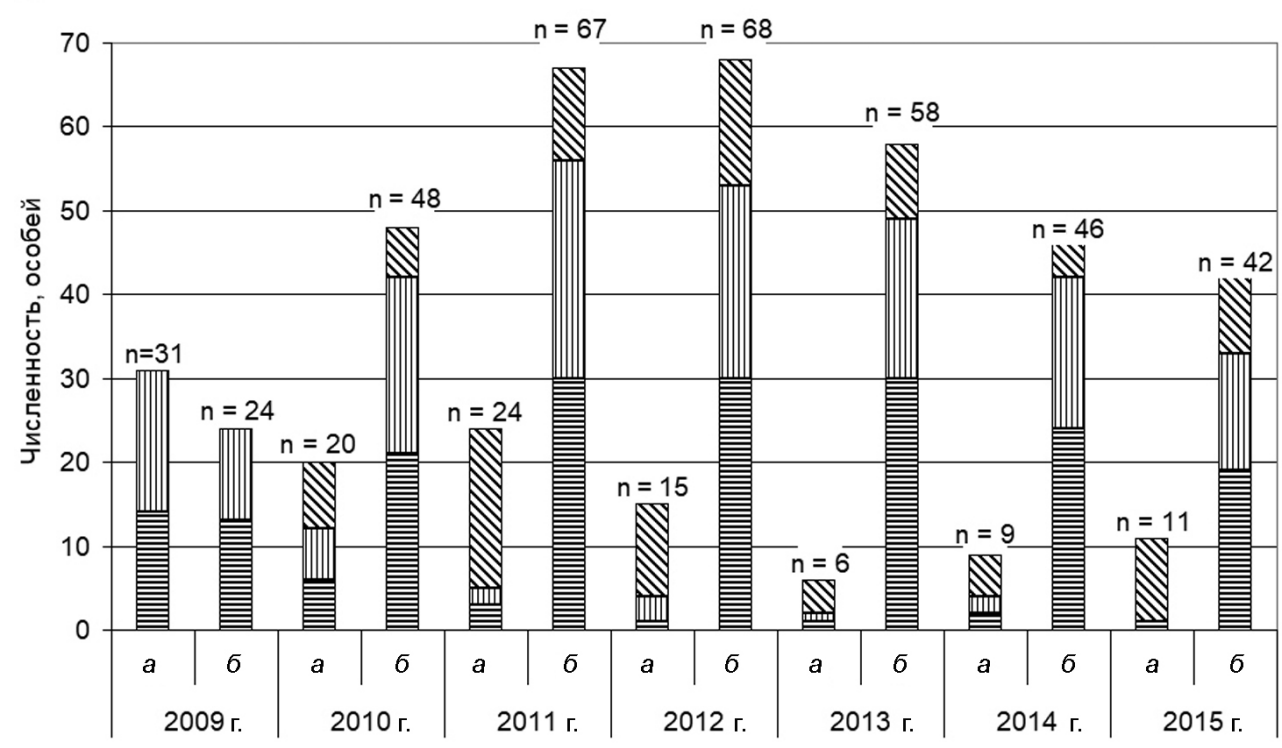

Pис. 4. Половозрастной состав населения кукши на площадке № 2 по данным кольцевания (без учета птиц местного приплода). Возраст птицы: $a-1-2+$ года, $\sigma-3-9+$ лет. Пол птицы: $三-$ самка, $\| \amalg-$ самец, Аा' - пол не определен

Fig. 4. Sex and age structure of the Siberian Jay population at Site 2 by the banding data ( except for the local off-

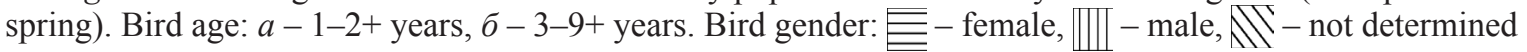

10 - два сезона (3 - в 2015 г.), 5 - три (2), 4 - четыре (1), 6 - пять (3), 2 - шесть (2) и 1 - семь (1) сезонов, в среднем $3.12 \pm 0.29$. Условный возраст самок составлял $3+\ldots$ 9+, в среднем $5.13 \pm 0.26+$ $(\mathrm{n}=37)$, самцов $-3+\ldots 8+$, в среднем $4.58 \pm 0.24+$ (n=41) лет.

Возрастная структура гнездящихся на площадке № 1 в 1992 г. птиц: 5+ лет - 3 пары, 6+1 самец, 7+ - 1 пара, 8+ лет -1 пара и 1 самка.

Репродуктивные пары на площадке № 2 составляют основу населения: 36.7 (2011г.) 70.6 (2015 г.), в среднем 50.6\% (см. табл. 3). На площадке № 1 с годами их состав существенно обновился: из пяти известных с 1987 г. пар к 1992 г. сохранились только две (в одной - со сменой самца). Значительно изменился со временем состав населения и репродуктивных пар площадки № 2. Из 55 окольцованных на ней в 2009 г. птиц в 2015 г. обнаружено 13 (23.6\%). Четыре из них встречены в трех сохранившихся с 2010 г. в неполном составе парах: в одной - самец (новая самка была окольцована в 2013 г.), в двух - самки (самец в одной паре был также окольцован в 2009 г., в другой - остался не идентифицированным). Из 22 гнездившихся птиц по истечении 5 лет обнаружено 3 (13.6\%), а из 11 известных пар в прежнем составе не сохранилось ни одной. Из остальных 9 ос., помеченных в начале исследований, одна не гнездилась, 8 состояли в сформированных в 2011-2015 гг. парах.

Репродуктивные пары составляли 59.0 (2011 г.) - 69.8\% (2010 г.) населения площадки во время размножения и 44.8 (2010 гг.) - 45.6\% (2009, 2011 г.) в предзимний период (см. табл. 4).

Смена партнеров в парах происходит лишь в случае гибели одного из них. На площадке

Таблица 8. Возрастной состав осевших в разные годы на территории площадке № 2 птенцов кукш местного приплода по данным кольцевания

Table 8. Age structure of the Siberian Jay nestlings of the local offspring, settled at Site 2 in different years, by the banding data

\begin{tabular}{|c|c|c|c|c|c|c|c|c|c|c|c|c|}
\hline \multirow{2}{*}{$\begin{array}{c}\text { Возраст, } \\
\text { лет }\end{array}$} & \multicolumn{2}{|c|}{$\begin{array}{l}2010 \text { г. } \\
(\mathrm{n}=2)\end{array}$} & \multicolumn{2}{|c|}{$\begin{array}{l}2011 \text { г. } \\
(\mathrm{n}=5)\end{array}$} & \multicolumn{2}{|c|}{$\begin{array}{l}2012 \text { г. } \\
(\mathrm{n}=5)\end{array}$} & \multicolumn{2}{|c|}{$\begin{array}{l}2013 \text { г. } \\
(\mathrm{n}=4)\end{array}$} & \multicolumn{2}{|c|}{$\begin{array}{l}2014 \text { г. } \\
(\mathrm{n}=6)\end{array}$} & \multicolumn{2}{|c|}{$\begin{array}{c}2015 \text { г. } \\
(\mathrm{n}=13)\end{array}$} \\
\hline & абс. & $\%$ & абс. & $\%$ & абс. & $\%$ & абс. & $\%$ & абс. & $\%$ & абс. & $\%$ \\
\hline 0.5 & 2 & 100 & 3 & 60.0 & 0 & 0 & 1 & 25.0 & 3 & 50.0 & 8 & 61.5 \\
\hline 1.5 & - & - & 2 & 40.0 & 3 & 60.0 & 0 & 0 & 1 & 16.6 & 3 & 23.1 \\
\hline 2.5 & - & - & - & - & 2 & 40.0 & 1 & 25.0 & 0 & 0 & 1 & 7.7 \\
\hline 3.5 & - & - & - & - & - & - & 2 & 50.0 & 1 & 16.7 & 0 & 0 \\
\hline 4.5 & - & - & - & - & - & - & - & - & 1 & 16.7 & 1 & 7.7 \\
\hline
\end{tabular}


№ 1 она отмечена в одной паре из 5, наблюдаемых от 3 до 6 репродуктивных сезонов (сменился самец). На площадке № 2 в 34 парах смена партнеров отмечена в 9: в двух - самок, в 7 - самцов (в одной паре у самки сменилиось два самца).

Как протокооперативный вид кукша отличается тем, что при ее репродуктивных парах могут держаться круглогодично, иногда в течение нескольких лет, одиночные, обычно молодые птицы - третий партнер (Коханов, 1982; Ekman et al., 1994; Гермогенов и др., 2002). Эти птицы не оказывают помощи приемным парам в заботе о потомстве, и сами далеко не всегда являются их птенцами.

На площадке № 1 эти пассивные (инертные) nартнеры отмечены у 10.0 (1988 г.) - 33.3\% (1990, 1992 г.) пар (в среднем 22.5). Из 23 персонализированных пар они отмечены у $6(26.1 \%)$ и во всех случаях не являлись их потомками. В марте 1988 г. три из них (две самки и самец) поодиночке присоединились к местным парам (21.7\%) и в последующем держались в них 1-3, в среднем 1.5 гнездовых сезона $(\mathrm{n}=6)$. В течение трех лет каждая из этих птиц создала пару и загнездилась неподалеку от места отлова. На площадке № 2 подобные партнеры ежегодно отмечались у 9.1 (2014 г.) - 33.3 (2010 г.), в среднем у 20.3\% пар. В 6 случаях из 18 это были «резиденты» инорайонного происхождения, в 5 - осевшие на территории местные птенцы (от сеголетков и старше), в 2 - «иммигранты» и в 5 - не идентифицированные птицы. Только одна годовалая птица держалась с родителями, остальные три - с другими парами (одна из них в одной и той же паре в течение двух лет).

Пребывание в гнездовых парах в качестве третьего партнера молодых птиц местного приплода и «иммигрантов» (от сеголетков и старше) способствует их выживанию и оседанию на территории (Ekman et al., 1999, 2001, 2002; Гермогенов и др., 2002; Ekman, Griesser, 2016).

В осенне-раннезимнее время кукши обычно формируют различные по численности группировки. На видовой площадке № 2 в сентябре 2009 г. из 57 птиц лишь одна держалась в одиночку, две - в паре, остальные - в 15 группировках из трех $(\mathrm{n}=9)$, четырех $(\mathrm{n}=3)$ и пяти $(\mathrm{n}=3)$, в среднем из 3.6 ос. В Швеции в это время группы состоят из близкого числа особей: $2-6$, в среднем 3.25 (Ekman, Griesser, 2016).

\section{ЗАКЛЮЧЕНИЕ}

Мониторинговые исследования состава населения кукши в таежной зоне Якутии с использованием видовых и комплексных учетных площадок свидетельствуют, что численность вида под- вержена пространственно-временной динамике. На двух видовых площадках: № 1 и 2 (далее площадки), заложенных в среднетаежных районах близ г. Якутск, численность птиц в зависимости от ландшафтно-экологических условий обитания менялась по сезонам и годам. Установлено, что в придолинных, испытывающих отепляющее влияние р. Лена, смешанных сосновых лесах (площадка № 1) плотность гнездования вида выше, чем в водораздельных, фрагментированных рубками, лиственничниках (№ 2): 1.8 против 1.4 пары/км². В северной тайге птицы гнездятся в соответствующих местообитаниях примерно с той же плотностью, но не регулярно. Вероятность их встреч на гнездовье в одних и тех же местообитаниях колеблется от 33.3 до $75 \%$, что может свидетельствовать об ослаблении у них «гнездового консерватизма».

Наблюдения на площадке № 2 свидетельствуют, что численность вида минимальна в пред- и гнездовой период (3.2-4.9 ос./км²) и максимальна в поствыводковый (4.2-5.8), когда происходят регулярные интенсивные перемещения инорайонных птиц, часть которых оседает на ее территории. Межгодовые изменения численности населения площадки имеют, вероятно, циклический характер. Они коррелировали с таковыми средних летних и годовых показателей температуры воздуха и определялись в основном соотношением сохранности постоянных обитателей площадки, притока и оседания на ней инорайонных птиц. При всей динамичности населения в целом количество ежегодно участвующих в воспроизводстве птиц менялось, при небольшой тенденции к росту, менее значительно. В оптимальных местообитаниях птицы стремятся максимально заполнить имеющиеся гнездовые ниши и реализовать репродуктивный потенциал независимо от практически ежегодно и сезонно меняющихся условий их размножения.

Роль местного приплода в пополнении населения конкретных местообитаний в целом и его постоянного контингента, в частности, наблюдаемом только на площадке № 2, несопоставимо низка по сравнению с таковой птиц инорайонного происхождения, ежегодно прибывающих извне ее территории и частично на ней оседающих. Это определяется низкой эффективностью воспроизводства вида в целом и малой сохранностью на территории местных сеголетков. Ситуация существенно не меняется и в годы, когда эффективность размножения бывает достаточно высокой. Вероятно, определенная часть приплода гибнет, выжившая - рассеивается, вытесняемая одновыводковыми особями-доминантами, заполняя свободные экологические ниши на других территориях обитания популяции и тем са- 
мым, что не менее важно, способствуя поддержанию ее генетического разнообразия. Можно полагать, что подобные периодически наблюдаемые локальные «вспышки» рождаемости и лежат в основе механизма саморегуляции численности популяции.

Население птиц характеризуется сложной структурой, определяемой их половозрастным составом, социальным статусом, происхождением и т. д. В него входят «резиденты»- осевшие на территории и ведущие оседлый образ жизни птицы местного («автохтоны») и инорайонного происхождения, составляющие основу населения, обеспечивающие его устойчивость и воспроизводство, и «иммигранты» - птицы, ежегодно впервые регистрируемые и кратковременно пребывающие на территории (не более полугода, нередко с гнездованием), придающие населению определенную динамичность.

Сохранность птиц в группах «резидентов» разных лет снижалась ежегодно, в основном однотипно и с близкой скоростью. Наиболее высокая сохранность была отмечена у птиц группы «резидент - 2010 г.» $(\mathrm{n}=44)$. Причем при сопоставлении результатов встречаемости этих птиц по отношению к предыдущему году она снижалась менее интенсивно, а в 2014 г. их сохранность была даже выше, чем в 2013 г.

Пропуски в размножении у постоянно находящихся в поле зрения репродуктивных пар«резидентов» не отмечались. Даже после гибели одной из птиц пары, сохранившаяся особь способна, сменив участок или оставшись на прежнем, загнездиться в очередной раз с новым партнером, не покидая площадки. Исчезновение «резидентов» (пар или одного из партнеров) с площадок отмечается вне зависимости от итогов их предыдущего размножения и, вероятнее всего, обусловлено гибелью птиц. Смена парами-«резидентами» гнездового участка наблюдалась лишь на площадке № 1. Наиболее вероятной причиной этого является предшествующее неудачное гнездование (Гермогенов и др., 2002). На площадке № 2 эта смена участков наблюдалась у отдельных птиц из распавшихся пар при их гнездовании с новым партнером. Смена участков гнездования происходила, в преобладающем большинстве, в пределах самих площадок. Дальняя гнездовая дисперсия (как и эмиграция) для «резидентов», вероятно, не характерна.

В населении, как правило, преобладают взрослые, половозрелые ( $\geq 3+$ года) особи (в среднем $79.5 \%$ состава без учета сеголетков), динамика численности которых по годам носит, вероятно, циклический характер, асинхронный таковой мо- лодых птиц ( $\leq 2+$ года). Предельно возможный в годы наблюдения возраст птиц, зарегистрированный на площадке № 2, - 9+ лет. В среднем 50.8\% взрослых птиц входят в состав участвующих в размножении пар. Часть репродуктивного населения (в среднем 20.3-22.5\% пар) имеет третьего (пассивного) партнера, обычно из числа «иммигрантов», не принимающего участие в заботе об их потомстве. Таким образом, эти птицы оседают на территории и впоследствии гнездятся по соседству с приемными парами.

Каких-либо закономерностей во временной динамике соотношения полов в различных возрастных группах птиц не выявлено. Отмечается лишь некоторое преобладание самцов.

Продолжительность гнездования идентифицированных пар достигала предельно возможной для периода наблюдений за ними (по площадкам - 6-7 лет), в среднем она примерно двое его короче (3.12 \pm 0.29 сезона против 7). При этом, с учетом достижения птицами половозрелости в три года, максимальный возраст самок в них также соответствовал предельно возможному (8+$9+$ лет), у самцов он был на год-два короче. Эти различия прослеживаются и при сопоставлении их среднего возраста (соответственно, 5.13+ \pm $0.26(n=37)$ и $4.58+ \pm 0.24$ (41) года).

В осенне-раннезимнее время кукши редко держатся поодиночке или в парах, обычно в группировках из 3-5, в среднем 3.6 птицы, что свойственно виду и в других частях его ареала.

Работа выполнена в рамках фундаментальных базовых проектов ИБПК СО РАН «Животное население приарктической и континентальной Якутии: видовое разнообразие, популяции и сообщества» (20132016 гг.) и «Структура и динамика популяций и сообществ животных холодного региона Северо-Востока России в современных условиях глобального изменения климата и антропогенной трансформации северных экосистем: факторы, механизмы, адаптации, сохранение» (2017-2020 гг.).

\section{ЛИТЕРАТУРА}

Андреев А. В. Адаптации птиц к зимним условиям Субарктики. М. : Наука, 1980. 176 с.

Андреев А. В. Зимняя экология кукши Perisoreus infaustus и кедровки Nucifraga caryocatactes на крайнем северо-востоке Сибири // Рус. орнитол. журн. 2006. № 15 (309). С. 111-123.

Андреев $A$. В. Особенности зимней экологии кукши и кедровки на крайнем северо-востоке Сибири // Орнитология. 1982. № 17. С. 72-82.

Андреев Б. Н. Птицы Вилюйского бассейна. Якутск : Кн. изд-во, 1974. 312 с.

Андреев Б. Н. Птицы Вилюйского бассейна. Якутск : Кн. изд-во, 1987. 192 с.

Андреев Б. Н. Птицы Среднего Вилюя. Якутск : Кн. изд-во, 1953. 128 с. 
Бардин А. В., Фетисов С. А. Кукша Perisoreus infaustus в Псковской области // Рус. орнитол. журн. 2016. № 25 (1286). С. 1763-1769.

Блинов В. Н. Врановые Западно-Сибирской равнины. М. : Тов-во науч. изданий КМК, 1998. 284 с.

Bapmanemoв Л. Г. Птицы северной тайги ЗападноСибирской равнины. Новосибирск : Наука, 1998. 327 с.

Владимирская М. И. Птицы Лапландского заповедника // Тр. Лапландского заповедника. М. : Совмин РСФСР, 1948. Вып. 3. С. 171-245.

Воробьев К. А. Птицы Якутии. М.: Изд-во АН CCCP, 1963. $336 \mathrm{c}$.

Воронов Н. П. Кукша // Птицы Волжско-Камского края. Воробьиные / отв. ред. В. А. Попов. М. : Наука, 1977. C. 47.

Гермогенов Н. И., Находкин Н. А., Осипов И. Ю., Егоров H. H. Материалы по филопатрии кукши Perisoreus infaustus в Центральной Якутии // Наземные позвоночные Якутии: экология, распространение, численность. Якутск : ЯФ изд-ва СО РАН, 2002. C. 5-17.

Гермогенов Н. И., Брунов В. В., Поздняков В. И. О смешанных гнездовых группировках лесных птиц в придельтовой части долины Лены // Сибир. экол. журн. 1997. № 6. С. 635-639.

Гермогенов Н. И., Егоров Н. Н., Секов А. Н. Структура населения кукши Perisoreus infaustus в Центральной Якутии // Рус. орнитол. журн. 2013а. № 23 (1013). С. 1894-1898.

Гермогенов Н. И., Егоров Н. Н., Секов А. Н., Лосоров A. B. Экология гнездования кукши Perisoreus infaustus (Corvidae) в Якутии // Вестник СВНЦ ДВО PAH. 2017. № 3. С. 100-114.

Гермогенов Н. И., Егоров Н. Н., Секов А. Н. Экология гнездования кукши (Perisoreus infaustus, Passeriformes) в Якутии // Современные проблемы орнитологии Сибири и Центральной Азии : Материалы V Междунар. орнитол. конф. (18-20 мая 2012 г.). Улан-Удэ : Изд-во Бурят. ун-та, 2013б. С. 186-190.

Гланц С. Медико-биологическая статистика. М. : Практика, 1999. 459 с.

Гылнгазов А. М., Миловидов С. П. Орнитофауна Западно-Сибирской равнины. Томск : Изд-во Томского ун-та, 1977. $351 \mathrm{c}$.

Данилов Н. Н. Количественные учеты при мониторинге и составление кадастров // Изучение птиц СССР, их охрана и рациональное использование : тез. докл. 1-го Всесоюз. орнитол. о-ва и IX Всесоюз. орнитол. конф. Л., 1986. Ч. 1. С. 187-188.

Кольцевание в изучении миграций птиц фауны СССР. М. : Наука, 1976. 256 с.

Коханов В. Д. К экологии кукши в Мурманской области // Экология и морфология птиц на крайнем северо-западе СССР : сб. науч. тр. ЦНИЛ Главохоты РСФСР. М., 1982. С. 124-137.

Кречмар А. В., Андреев А. В., Кондратьев А. Я. Птицы северных равнин. Л. : Наука, 1991. 288 с.
Кречмар А. В., Андреев А. В., Кондратьев А. Я. Экология и распространение птиц на северо-востоке СССР. М. : Наука, 1978. 196 с.

Лакин Г. Ф. Биометрия : учеб. пособие для биологич. спец. вузов. М. : Высш. шк., 1980. 293 с.

Ларионов Г. П., Гермогенов Н. И., Сидоров Б. И. Фауна и экология зимующих птиц Лено-Вилюйского междуречья // Фауна и экология наземных позвоночных таежной Якутии. Якутск : Изд-во ЯГУ, 1980. C. 85-141.

Мальчевский А. С., Пукинский Ю. Б. Птицы Ленинградской области и сопредельных территорий. Л. : Изд-во Ленинград. ун-та, 1983. Т. 2. 504 с.

Нечаев В. А. Птицы острова Сахалин. Владивосток : ДВО АН СССР, 1991. 748 с.

Определение пола и возраста воробьиных птиц фауны СССР : справочник. М. : Наука, 1976. 180 с.

Равкин Ю. С. Пространственная организация населения птиц лесной зоны (Западная и Средняя Сибирь). Новосибирск : Наука, 1984. 262 с.

Реймерс $H$. Ф. Птицы и млекопитающие южной тайги Средней Сибири. М. ; Л. : Наука, 1966. 420 с.

Рогачева Э. В. Птицы Средней Сибири. Распространение, численность, зоогеография. М.: Наука, 1988. 309 c.

Рустамов А. К. Семейство вороновые Corvidae // Птицы Советского Союза. М., 1954. Т. 5. С. 13-104.

Семенов-Тян-Шанский О. И., Гилязов А. С. Птицы Лапландии. М. : Наука, 1991. 228 с.

Сыроечковский Е. Е., Рогачева Э. В. Животный мир Красноярского края. Красноярск, 1980. 359 с.

Юдкин B. А. Птицы подтаежных лесов Западной Сибири. Новосибирск : Наука, 2002. 488 с.

Blomgren A. Studies of less familiar birds. 162. Siberian jay // British Birds. 1971. 64. P. 25-28.

Cramp S., Perrins C. M. Handbook of the birds of Europe, the Middle East and North Africa // The birds of the western Palearctic. Oxford: Oxford University Press, 1994. Vol. 8. P. 31-42.

Ekman J., Eggers S., Griesser M. Fighting to stay: the role of sibling rivalry for delayed dispersal // Anim. Behav. 2002. 64. P. 453-459.

Ekman J., Bylin A., Tegelström H. Increased lifetime reproductive success for Siberian jay (Perisoreus infaustus) males with delayed dispersal // Proc. R. Soc. London B. 1999. 266. P. 911-915.

Ekman J., Schlepkovych B., Tegelström H. Offspring retention in the Siberian jay (Perisoreus infaustus): the prolonged brood care hypothesis // Behavioral Ecology. 1994. 5. P. 245-253.

Ekman J., Eggers S., Griesser M., Tegelström $H$. Queuing for preferred territories: delayed dispersal of Siberian jays // J. Anim. Ecol. 2001. 70. P. 317-324.

Ekman Jan Bertil, Griesser Michael. Siberian jays: delayed dispersal in the absence of cooperative breeding // Cooperative Breeding: Studies of Ecology, Evolution, and Behavior. Chapter 1. Ed. W. Koenig, J. L. Diскіnson. Cambridge University Press, 2016. P. 6-18. 


\title{
SIZE AND STRUCTURE OF THE SIBERIAN JAY PERISOREUS INFAUSTUS (AVES, PASSERIFORMES) POPULATION IN YAKUTIA
}

\author{
N. N. Yegorov, N. I. Germogenov, A. N. Sekov, A. V. Losorov \\ Institute for Biological Problems of Cryolithozone, SB RAS, Yakutsk
}

\begin{abstract}
Studies were conducted in various sub-zones of Yakutia's taiga in 1975-2015. At the two species model sites (471 and 1360.3 ha) in light-coniferous forests near Yakutsk, they were of a monitoring character: counting numbers, determining the status of birds on the basis of banding, etc. The number of birds is subject to space-time dynamics. The nesting density of the species varies depending on the landscape and environmental conditions. The species inhabits the Northern taiga, with the less pronounced "nest-site fidelity". The number of birds is minimal in pre-nesting and nesting periods; maximum, in post-breeding. Its changes over the years are probably cyclic and correlated with the dynamics of some mean annual air temperature. It is assumed that, under the influence of such demographic features of the species as low efficiency of reproduction and low survival in the territory of the birth of juveniles, it has formed a specific mechanism of regulating population. The replacement of population losses is probably provided by periodically observed local "outbreaks" of fertility. Due to the wide natal dispersion, determined by severe intra-brood competition among young birds, most of them are redistributed over the territory occupied by the population outside their brthplaces. There are two main categories of birds distinguished in the population: "residents" (birds of foreign and local origin settled in the territory, forming the basis of the population, and ensuring its stability and reproduction) and "immigrants" (birds each year registered for the first time, shortly staying (sometimes nesting) in the area, and giving a certain dynamism to the population. About half of the bird population, which is dominated by individuals from $3+$ years of age and older, make pairs; the duration of their nesting without changing partners reaches at least 7 seasons. The maximum age of females is $9+$ years, which corresponds to the maximum possible one for the observation period; males, $8+$ years. Some pairs have a passive (inert) partner, usually an "immigrant".
\end{abstract}

Keywords: Yakutia, Siberian Jay, sex-age composition of population, bird status.

\section{REFERENCES}

Age and Sex Identification of USSR Passerine Birds in the USSR Fauna, 1976, Moscow, Nauka [In Russian]. Andreev, A. V., 1980, Bird Adaptations to Winter Conditions in the Subarctic, Moscow, Nauka [In Russian].

Andreev, A. V., 1982, Features of Winter Ecology of the Siberian Jay and Nutcracker in the Far North-East of Siberia, Ornithologia, 17, 72-82 [In Russian].

Andreev, A. V., 2006, Winter Ecology of the Siberian Jay Perisoreus infaustus and Nutcracker Nucifraga caryocatactes in the Far North-East of Asia, The Russian Journal of Ornithology, 15, 309, 111-123 [In Russian]. Andreev, B. N., 1953, Birds of the Middle Vilyuy River, Yakutsk [In Russian].

Andreev, B. N., 1974, Birds of the Vilyuy River Basin, Yakutsk [In Russian].

Andreev, B. N., 1987, Birds of the Vilyuy River Basin,

Yakutsk [In Russian].

Banding in the Study of Bird Migration of the USSR Fauna, 1976, Moscow, Nauka [In Russian].

Bardin, A. V.; Fetisov, S. A., 2016, Siberian Jay Perisoreus infaustus in Pskov Oblast, The Russian Journal of Ornithology, 25, 1286, 1763-1769 [In Russian].

Blinov, V. N., 1998, Corvids of the West Siberian

Plain, Moscow, KMK Scientific Press Ltd. [In Russian]. Blomgren, A., 1971, Studies of Less Familiar Birds, 162, Siberian Jay, British Birds, 64, 25-28.
Cramp, S.; Perrins, C. M., 1994, Handbook of the Birds of Europe, the Middle East and North Africa, The Birds of the Western Palearctic, Oxford University Press, Oxford, 8, 31-42.

Ekman, J.; Bylin, A.; Tegelström, H., 1999, Increased Lifetime Reproductive Success for Siberian Jay (Perisoreus infaustus) Males with Delayed Dispersal, Proc. R. Soc., London B, 266, 911-915.

Ekman, J.; Eggers, S.; Griesser, M., 2002, Fighting to Stay: the Role of Sibling Rivalry for Delayed Dispersal, Animal Behavior, 64, 453-459.

Ekman, J.; Eggers, S.; Griesser, M.; Tegelström, H., 2001, Queuing for Preferred Territories : Delayed Dispersal of Siberian Jays, Journal of Animal Ecology, 70, 317-324.

Ekman, J.; Griesser, M., 2016, Siberian Jays: Delayed Dispersal in the Absence of Cooperative Breeding, Cooperative Breeding: Studies of Ecology, Evolution, and Behavior, Chapter 1, Ed. W. Koenig, J. L. Dickinson, Cambridge University Press, 6-18.

Ekman, J.; Schlepkovych, B.; Tegelström, H., 1994, Offspring Retention in the Siberian Jay (Perisoreus infaustus): the Prolonged Brood Care Hypothesis, Behavioral Ecology, 5, 245-253.

Germogenov, N. I.; Brunov, V. V.; Pozdnyakov, V. I., 1997, On Mixed Nesting Groups of Forest Birds in the Delta Part of the Lena Valley, Contemporary Problems of Ecology, 6, 635-639 [In Russian]. 
Germogenov, N. I.; Egorov, N. N.; Sekov, A. N., 2013b, Ecology of the Siberian Jay (Perisoreus infaustus, Passeriformes) Nesting in Yakutia, Materials of V International Ornitological Conf. "Modern Problems of Ornithology in Siberia and Central Asia”, 18-20 May 2012, Ulan-Ude, 186-190 [In Russian].

Germogenov, N.I.; Yegorov, N. N.; Sekov, A. N., 2013a, Structure of the Siberian Jay Perisoreus infaustus Population in Central Yakutia, The Russian Journal of Ornithology, 2013, 1894-1898 [In Russian].

Germogenov, N. I.; Yegorov, N. N.; Sekov, A. N.; Losorov, A. V., 2017, Ecology of the Siberian Jay Perisoreus infaustus (Corvide) Nesting in Yakutia, Bulletin of the North-East Science Center, 3, 100-114 [In Russian].

Germogenov, N. I.; Nakhodkin, N. A.; Osipov, I. Yu.; Yegorov, N. N., 2002, Materials on Philopatry of the Siberian Jay Perisoreus infaustus in Central Yakutia, Terrestrial Vertebrates in Yakutia: Ecology, Distribution, Population, Scientific Works, Yakutsk, Yakutsk Branch, Publishing House SB RAS, 5-17 [In Russian].

Glants, S., 1999, Medical and Biological Statistics, Moscow, Praktika [In Russian].

Gyngazov, A. M.; Milovidov, S. P., 1977, Avifauna of the West Siberian Plain, Tomsk, Izd-vo Tomskogo Universiteta [In Russian].

Danilov, N. N., 1986, Quantitative Surveys in Monitoring and Inventory Compilation, Study of Birds of the USSR, Their Protection, and Rational Use, Abstracts of the $1^{\text {st }}$ All-Russia Ornithol. Society and IX All-Russia Ornithol. Conference, Leningrad, Part 1, 187-188 [In Russian].

Kokhanov, V. D., 1982, On the Ecology of the Siberian Jay in the Murmansk Oblast, Ecology and Morphology of Birds in the Far North-West of the USSR, Sbornik Nauchnykh Trudov TSNIL Glavokhoty, Moscow, Nauka, 124-137 [In russian].

Krechmar, A. V.; Andreev, A. V.; Kondratiev, A. Ya., 1978, Ecology and Distribution of Birds in the North-East of the USSR, Moscow, Nauka [In Russian].
Krechmar, A. V.; Andreev, A. V.; Kondratiev, A. Ya., 1991, Birds of the Northern Plains, Leningrad, Nauka [In Russian].

Lakin, G. F., 1980, Biometry, Moscow, Vysshaya Shkola [In Russian].

Larionov, G. P.; Germogenov, N. I.; Sidorov, B. I., 1980, Fauna and Ecology of Wintering Birds of the LenaVilyui Interfluve, Fauna and Ecology of Terrestrial Vertebrates in the Taiga Yakutia, Yakutsk, Izd-vo YaGU, 85141 [In Russian].

Malchevsky, A. S.; Pukinsky, Yu. B., 1983, Birds of the Leningrad Oblast and Adjacent Territories, Leningrad, Izd-vo LGU, 2 [In Russian].

Nechaev, V.A., 1991, Birds of Sakhalin Island, Vladivostok, DVO AN SSSR [In Russian].

Ravkin, Yu. S., 1984, Spatial Organization of Bird Populations in the Forest Zone (West and Central Siberia), Novosibirsk, Nauka [In Russian].

Reimers, N. F., 1966, Birds and Mammals of Central Siberia's Southern Taiga, Moscow - Leningrad, Nauka

[In Russian].

Rogacheva, E. V., 1988, Birds of the Middle Siberia, Moscow, Nauka [In Russian].

Rustamov, A. K., 1954, Crows Family Corvidae, Birds of the Soviet Union, 5, 13-104 [In Russian].

Semenov-Tyan-Shanskiy, O. I.; Gilyazov, A. S., 1991, Birds of Lapland, Moscow, Nauka [In Russian]. Syroechkovski, E. E.; Rogacheva, E. V., 1980, Wildlife of Krasnoyarsk Krai, Krasnoyarsk [In Russian]. Vartapetov, L. G., 1998, Birds of Northern Taiga of the West-Siberian Plain, Novosibirsk, Nauka [In Russian]. Vladimirskaya, M. I., 1948, Birds of the Lapland Nature Reserve, Trudy Laplandskogo Zapovednika, Moscow, Sovmin RSFSR, Iss. 3, 171-245 [In Russian]. Vorobyev, K. A., 1963, Birds of Yakutia, Moscow, Izd-vo AN SSSR Publisher [In Russian].

Voronov, N. P., 1977, Siberian Jay, Birds of the Volga-Kama Territory: Passerines, Moscow, Nauka, 47 [In Russian].

Yudkin, V. A., 2002, Birds of Sub-Taiga Forests of West Siberia, Novosibirsk, Nauka [In Russian]. 